\title{
Influence of humic acid application on phenology, leaf area and production duration of okra (Abelmoschus esculentus L.) cultivars
}

\author{
Nadeem Haider ${ }^{1 *}$, Mehboob Alam ${ }^{1}$, Abid Khan ${ }^{3}$, Waseem Haider ${ }^{2}$, \\ Sadiq Hussain ${ }^{2}$ and Shah Zeb ${ }^{1}$ \\ 1. Department of Horticulture, The University of Agriculture, Peshawar-Pakistan \\ 2. Department of Soil and Environmental Sciences, The University of Agriculture, Peshawar-Pakistan \\ 3. College of Horticulture, North West A and F University, Yangling, Shaanxi-China \\ *Corresponding author's email: nadeemjan529@aup.edu.pk \\ Citation
}

Nadeem Haider, Mehboob Alam, Abid Khan, Waseem Haider, Sadiq Hussain and Shah Zeb. Influence of humic acid application on phenology, leaf area and production duration of okra (Abelmoschus esculentus L.) cultivars. Pure and Applied Biology. Vol. 6, Issue 3, pp1010-1020. http://dx.doi.org/10.19045/bspab.2017.600107

\begin{tabular}{llll}
\hline \hline Received: 17/03/2017 & Revised: 15/08/2017 & Accepted: 25/08/2017 & Online First: 28/08/2017 \\
\hline
\end{tabular}

\section{Abstract}

Response of four okra cultivars (Sabz Pari, Green Star, Arka Anamika and Pusa Sawani) to four humic acid levels $\left(10,20,30\right.$ and $\left.40 \mathrm{~kg} \mathrm{ha}^{-1}\right)$ along with control were studied during AprilAugust, 2015 at Dargai, District Malakand, Khyber Pakhtunkhwa-Pakistan. The experiment was performed in randomized complete block design with split plot arrangement. Different levels of humic acid were prepared and soil applied before seed sowing. Results indicated that cultivar Arka Anamika showed minimum days to emergence (6.87), first flowering (42.60 days), first picking (48.80 days) and maximum single leaf area $\left(150.43 \mathrm{~cm}^{2}\right)$ and longer production duration (74.00 days) while cultivar Pusa Sawani showed maximum number of leaves (27.87). The maximum oven dried leaf weight $(1.10 \mathrm{~g})$ was noticed in cultivar Sabz Pari. Applications of humic acid@20 kg ha-1 showed minimum days to first flowering (47.75), first picking (47.75 days), maximum leaf area $\left(150.25 \mathrm{~cm}^{2}\right)$, oven dried single leaf weight $(1.23 \mathrm{~g})$ and longer production duration (74.50 days). The application of humic acid @ $30 \mathrm{~kg} \mathrm{ha}^{-1}$ produced maximum (28.25) number of leaves plant ${ }^{-1}$. While non-significant effect on days to emergence was observed. On the basis of current experiment, it can be recommended that cultivar Arka Anamika should be used with the application of humic acid @ $20 \mathrm{~kg} \mathrm{ha}^{-1}$ under the agroclimatic conditions of Dargai, district Malakand, Khyber Pakhtunkhwa-Pakistan to attain better growth for earlier and prolong production duration of okra for higher yield.

Keywords: Humic acid levels; Okra cultivars; Phenology

\section{Introduction}

Okra is a tropical and subtropical summer vegetable which is grown worldwide. Botanically it is known as Abelmoschus esculentus L. and belongs to family Malvaceae. In Pakistan it is also known as ladyfinger and bhendi. Probably it is originated from Ethiopian region of Africa. 
It is suitable for both kitchens gardening as well as on large scale for commercial purpose [1]. Majority of the area in Pakistan has suitable climatic conditions for the cultivation of okra but still the average yield per unit area is low as compared to other countries. The low yield might be due to low nutrition, environmental factors or genotype of the crop [2]. Different genotypes respond differently to environmental and climatic conditions, which results variation in most of the traits including; pod length, number of pods, pod weight and number of seeds pod ${ }^{-1}$ and therefore ultimately determine green pod and seed yield [3]. With improved cultural practices it is necessary to fulfill the nutrients requirement of the crop and grow high yielding cultivars to get optimum fresh pod yield.

Addition of organic matters improves soil fertility and increases plant growth and yield. Humic acid is one of the most abundant forms of organic matter which is considered the most important component of fertile soils $[4,5]$. Humic acid has important role in improving the chemical, physical and biological characteristics of the soil [6]. It has $50-90 \%$ cation absorbing capacity of mineral soils and hold the nutrients cations including; calcium, magnesium, potassium etc., in easily exchangeable form and prevent their leaching from soil profile with peculating water [6]. It also effects the composition of microbial populations in the soil and thus affects the biological characteristics of the soils [4]. Supplementation of crop with humic acid has drastic effect in active metabolism of plants, as it increases the respiratory activities of plants due to the presence of quinon groups [7]. Many researchers reported that application of humic acid to the soil, increase the uptake of macro and micro nutrients including; phosphorous, nitrogen, potassium, iron and zinc etc., and hence playing drastic role in the fulfillment of the nutrient requirements of the plant [8]. When the soil $\mathrm{pH}$ and temperature are unfavorable for plant growth, it shows antistress effect and helps the plant to withstand in adverse environmental conditions [9].

Keeping in view the importance of different genotypes and nutrients requirements of the plant for obtaining better growth for earlier and prolong production, the present study was conducted to test four okra cultivars in response to four levels of humic acid along with control for their phenological characteristics, leaf area and fruiting duration.

\section{Materials and methods}

\section{Experimental site and field preparation}

The study was conducted in farmer field at Dargai, district Malakand, Khyber Pakhtunkhwa-Pakistan during April-August, 2015. The experiment was laid out in randomized complete block design with split plot arrangement with three replications. Each replication consists of 5 main-plots of size $5.40 \mathrm{~m} \times 1.50 \mathrm{~m}$, each main plot was divided into 4 sub-plots of size $1.35 \mathrm{~m} \times$ $1.50 \mathrm{~m}$. Four okra cultivars (Sabz Pari, Green Star, Arka Anamika and Pusa Sawani) were allotted to main plots while four levels of humic acid (10, 20, 30 and 40 $\mathrm{kg} \mathrm{ha}^{-1}$ ) along with control were applied to the sub-plots. The distance between plantplant was maintained $30 \mathrm{~cm}$ while row to row distance was kept at $45 \mathrm{~cm}$ in each plot. In each sub-plot a total of fifteen (15) plants were planted in three rows, each row consists of five (5) plants.

Pre-sowing physicochemical test of the soil was performed, so as to identify the soil profile. The soil test of the research field showed $\mathrm{pH} 7.83$, EC $0.26 \mathrm{dS} \mathrm{m}^{-1}$, nitrogen present in the soil was recorded $2625 \mathrm{mg} \mathrm{kg}^{-}$ ${ }^{1}$, phosphorous was $11.59 \mathrm{mg} \mathrm{kg}^{-1}$ and potash was $88 \mathrm{mg} \mathrm{kg}^{-1}$ while organic matter was recorded $0.992 \%$ in the soil sample.

A recommended dose of N-P-K (120-60-60) [1] was applied as a basal dose in each plot 
uniformly in the form of Urea, SSP and NPK (17-17-17). Nitrogen was applied in two split doses, half was applied during seedbed preparation while half was applied after 30 days of emergence.

Preparation and soil application of humic acid

Humic acid was procured from local market with brand name Land Saver® of Mahan Agrochemical Company. The product contains $50 \%$ humic acid, so the source was applied in double amount to the experimental plots. Once the seedbeds were prepared for sowing okra seeds, the humic acid source was applied at a rate of 4.05, 8.10, 12.15 and $16.20 \mathrm{~g} \mathrm{plot}^{-1}$ respectively, so as to obtain humic acid levels of 10, 20, 30 and $40 \mathrm{~kg} \mathrm{ha}^{-1}$. No humic acid was applied to the control plots.

\section{Seed sowing}

Seeds of all four okra cultivars were soaked for $24 \mathrm{hrs}$ in distilled water before sowing so as to encourage germination. Sowing was performed in each plot, at each sowing spot, three okra seeds were sown so as to eliminate the chance of plant missing due to germination failure and after germination thinning was performed to maintain the desired planting density. All cultural practices including; irrigation, hoeing, earthing, fertilizer application and weeding was practiced uniformly in each plot.

\section{Data collection}

The data was collected on the following study attributes to compare the response of okra cultivars to humic acid levels on various characteristics.

\section{Days to emergence}

Days taken from sowing to $50 \%$ seed emergence of various treatments were counted and the average of all three replications of a treatment was calculated.

\section{Days to first flowering}

After seed emergence ten plants in each treatment were randomly selected for days to first flowering. The days from seed sowing to the flowering of $50 \%$ of selected plants were counted and average of three replications for each treatment was calculated.

\section{Days to first picking}

The days from sowing to the $50 \%$ of selected plants to first picking produce were counted and averages of all treatments were calculated.

\section{Leaf area $\left(\mathrm{cm}^{2}\right)$}

Randomly five plants in each treatment were selected for leaf area measurement. From each plant three types of leaves; top, middle and bottom leaves were selected for measuring leaf area through digital leaf area meter and the average of these three leaves were calculated for single plant and then for each treatment the average of selected five plants in each replication were calculated.

\section{Number of leaves}

The number of leaves were counted in randomly selected five plants in each treatment and the average of it were calculated. The average of all replications was carried out for each treatment.

\section{Oven dried single leaf weight (g)}

The leaves used for leaf area measurement of each treatment was oven dried for $48 \mathrm{hrs}$ at $60{ }^{\circ} \mathrm{C}$ and then their weighing was carried out through electronic balance and the average for each treatment was calculated.

\section{Production duration}

Days from first picking to last picking for each treatment in each replication were counted and its average was calculated.

\section{Statistical analysis}

Statistical analysis was carried out at 5\% level of significance through statistical software named "Statistix".

\section{Results and discussion}

Days to emergence

Figure 1 shows days to emergence of various okra cultivars in response to different levels of humic acid. The results showed that emergence duration was significantly affected by different okra 
cultivars, whereas the application of humic acid doses has non-significant effect on days to emergence. Among okra cultivars, cv. Arka Anamika showed early seed emergence (6.87 days) followed by Pusa Sawani and Sabz Pari while Green Star showed maximum ( 8.47 days) to emergence. It might be due to their genetic diversity which affects emergence potential of a seed. The results are correlated with the findings of $[1,10]$ who found significant variation in days to emergence of okra genotypes.

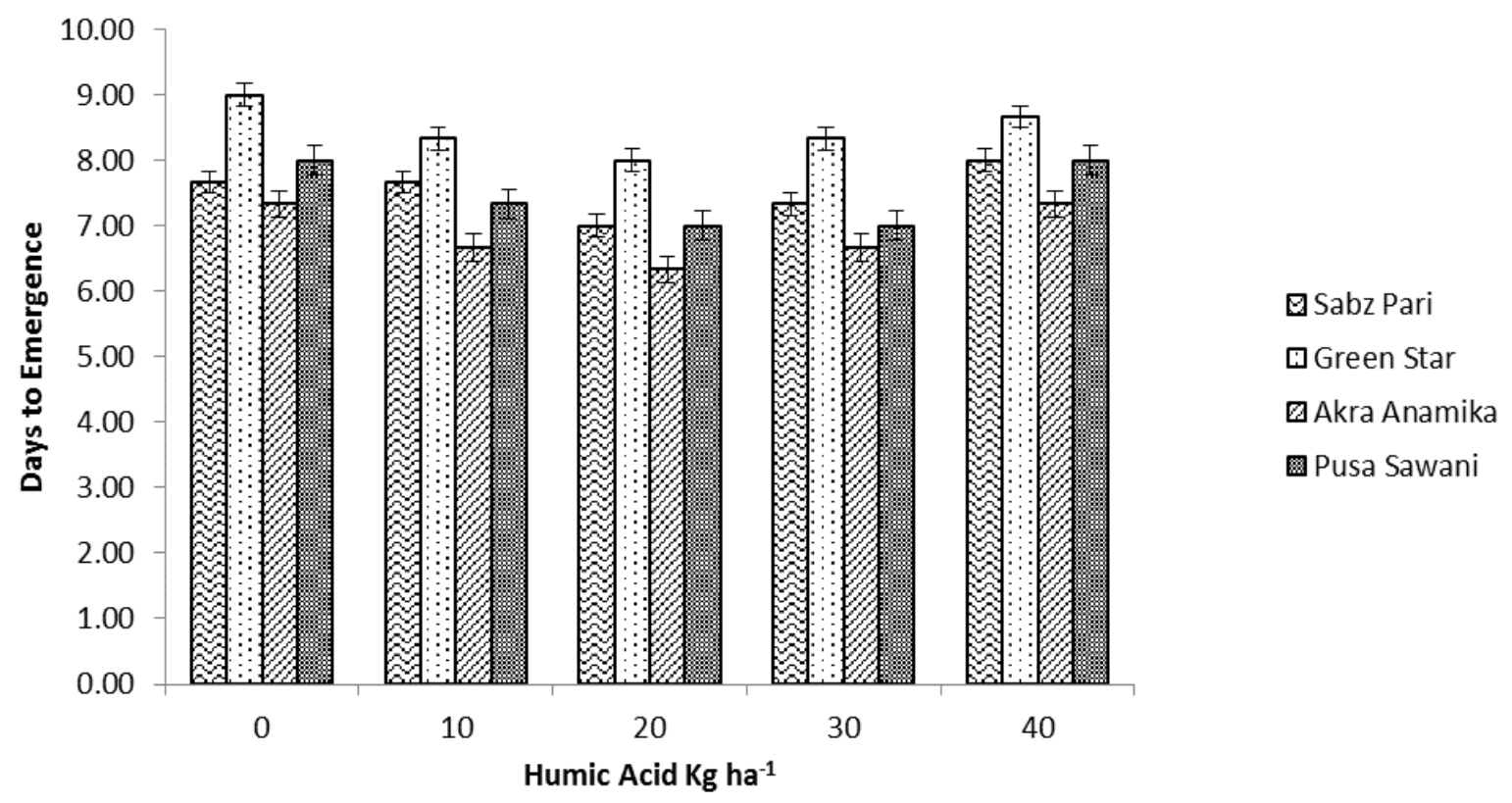

Figure 1. Days to emergence of different okra cultivars as affected by humic acid levels. Each bar represents average days taken to $50 \%$ plants emergence of different okra cultivars in response to various levels of humic acid. The error bar on each vertical bar shows standard error

\section{Days to first flowering}

Data regarding first flowering are presented in Figure 2. Statistical analysis of data showed significant response of okra cultivars to humic acid application for days to first flowering. Cultivar Arka Anamika showed minimum days to first flowering (42.60), whereas maximum (45.87) days to first flowering were recorded in cultivar Green Star. The variation in first flowering among different cultivars might be due to their genetic variation and adoptability to the climatic conditions of the study area. A correlated study of [11] also reported significant fluctuations in flowering among okra cultivars. Application of humic acid @ $20 \mathrm{~kg} \mathrm{ha}^{-1}$ resulted significantly minimum days to flowering (41.75) followed by 30 and $40 \mathrm{~kg} \mathrm{ha}^{-1}$ while maximum days to first flowering (47.33) was recorded in control plots. It might be due to the role of humic acid in biological processes including photosynthesis and respiration. Humic acid enhance the chlorophyll content in leaves and boost up the uptake of nutrients from the soil which played important role in early flowering. The similar findings were reported by [24] reported when humic acid was applied to pepino (Solanum muricatum). 




Figure 2. Days to first flowering of different okra cultivars as affected by humic acid levels. Each bar represents the averages days taken to $50 \%$ plants flowering of each cultivars in response to various levels of humic acid. The error bar on each vertical bar shows standard error

\section{Days to first picking}

The data regarding days to first picking are presented in Figure 3. The current study showed significant response of okra cultivars to humic acid levels in first fruiting of okra. Cultivar Arka Anamika provided significantly early first picking after (48.80) days of sowing while cv. Green showed late first picking after (52.07) days of sowing. Difference in genotype affects various characteristics including; growth pattern, photosynthesis efficiency, and tolerance toward biological and environmental stress which are the key factors for growth and yield. Cultivar Arka Anamika provided early picking as compared to other under test cultivars it might be due to their more adoptability and suitability with the climatic conditions of the study area. In early study [1] also reported significant difference in first picking of okra cultivars.

The amendment of humic acid @ $20 \mathrm{~kg} \mathrm{ha}^{-1}$ showed minimum days to first picking (47.75) which is at par with $30 \mathrm{~kg} \mathrm{ha}^{-1}$ while maximum days to first picking (54.17) was recorded in control plots. It might due to increase in nutrient uptake due to humic acid. Humic acid act like hormone in plant body and play a major role in cell elongation and improve fungal and microbial activities in the soil. [12-14] also reported early flowering in okra with the application of humic acid. 


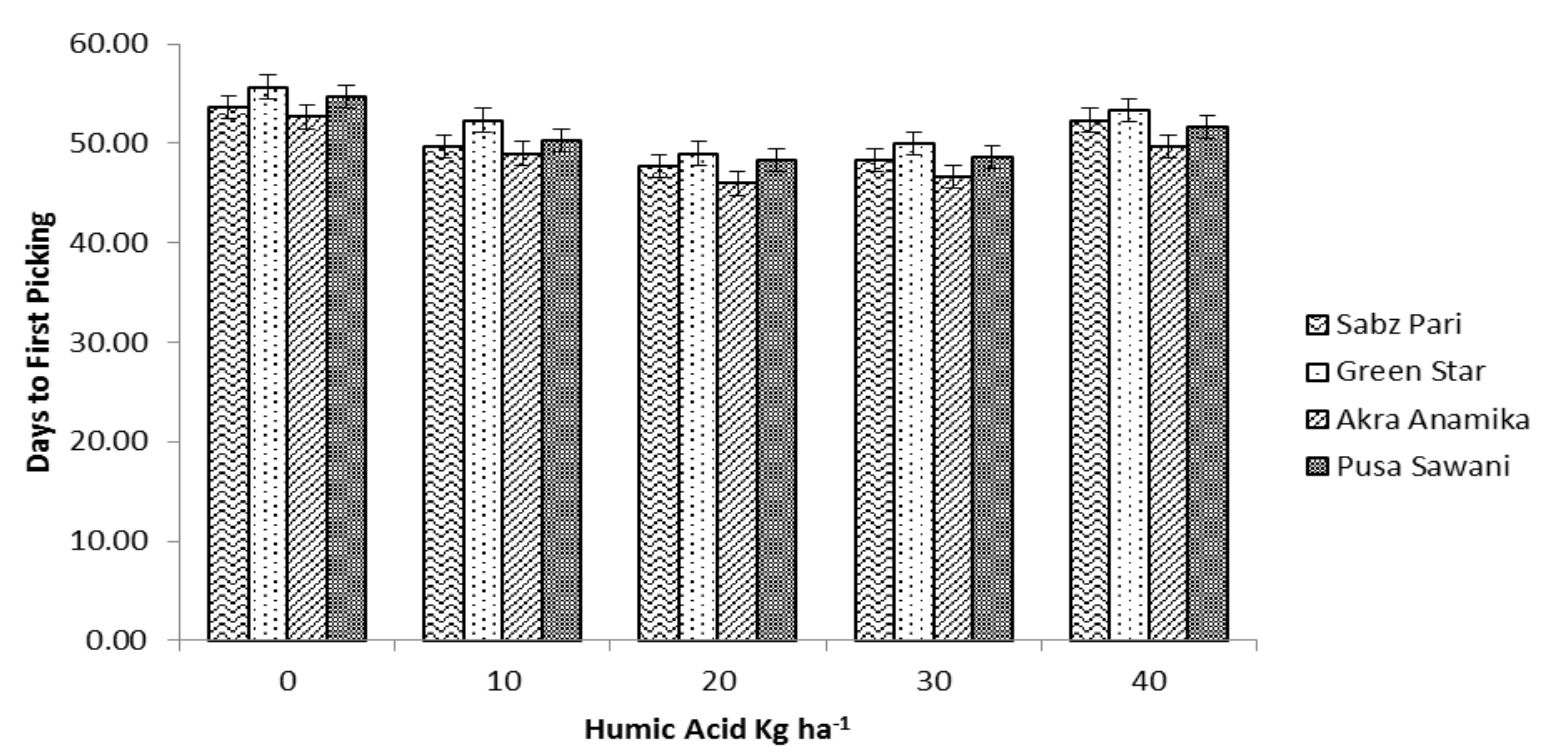

Figure 3. Response of okra cultivars in first picking to various levels of humic acid. Each bar represents the average days taken to first picking of different okra cultivars in response to various levels of humic acid. The error bar on each vertical bar shows standard error

\section{Single leaf area $\left(\mathrm{cm}^{2}\right)$}

Figure 4 shows data regarding single leaf area of okra in response to humic acid. The analysis of collected data showed significant role of humic acid on leaf area of okra. Maximum leaf area $\left(150.43 \mathrm{~cm}^{2}\right)$ was noticed in cultivar Arka Anamika followed by Pusa Sawani and Sabz Pari while minimum leaf area $\left(144.63 \mathrm{~cm}^{2}\right)$ was recorded in cv. Green Star. The variation in leaf area might be due to more adaptability, genetic compositions and suitability with environmental conditions of the study area of some cultivars more than others. The findings of the research are correlated with $[15,16]$ who reported significant variations in leaf area of different okra cultivars.

Maximum leaf area $\left(150.25 \mathrm{~cm}^{2}\right)$ was recorded when humic acid was applied @ 20 $\mathrm{kg} \mathrm{ha}^{-1}$ while minimum leaf area (146.03 $\mathrm{cm}^{2}$ ) was noticed in control plots.

Leaf area is directly proportional to the rate of photosynthesis which is the key factor of high quality and yield of a crop. The increase in leaf area might be due to increase in soil porosity, roots development and increase in nutrients uptake, such as nitrogen which is one of the basic elements for better vegetative growth of plant. Humic acid had the ability to improve ventilation, root respiration and boost up the biological processes in the soil which results in maximum nutrients availability and improve plant growth. The correlated study of [17] also reported significant increase in leaf area index of cowpea with addition of humic acid. 


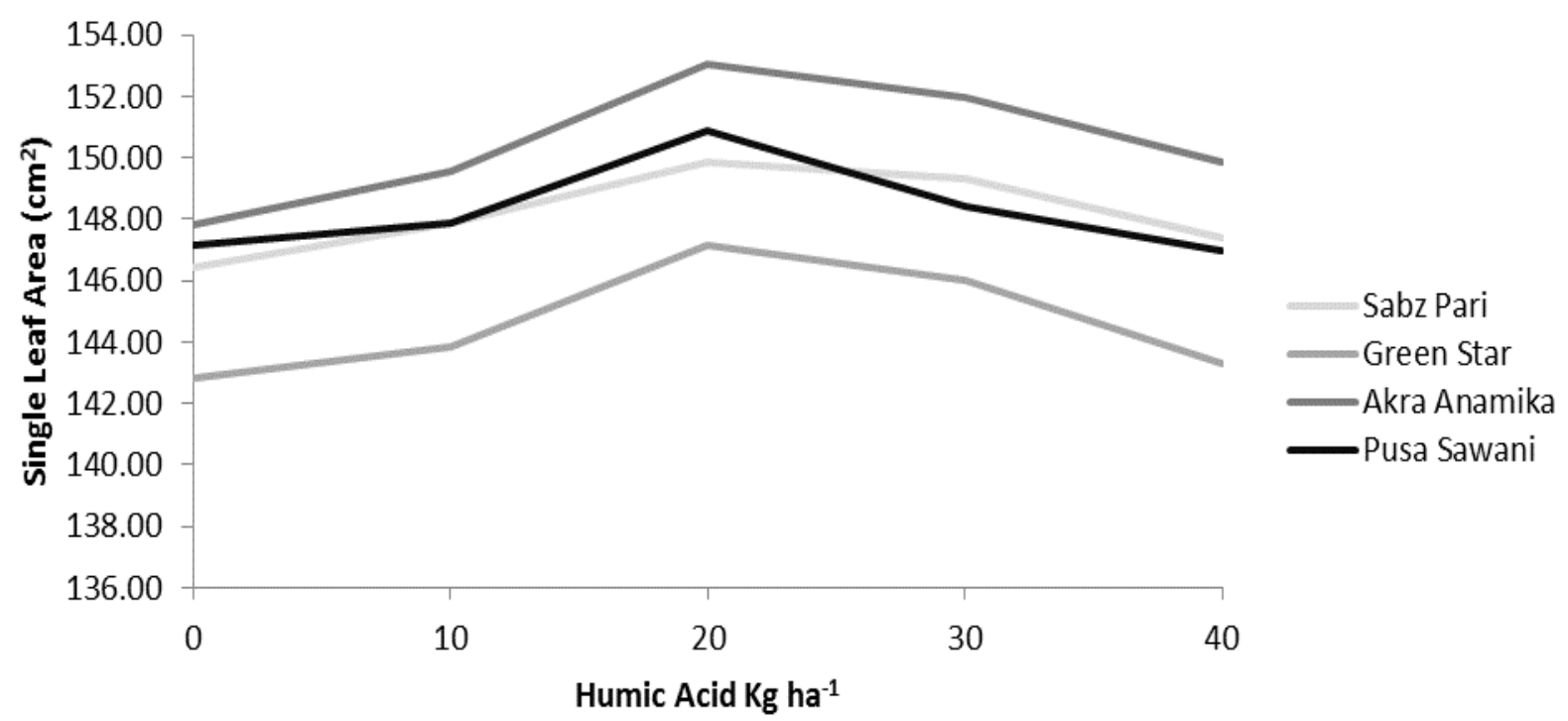

Figure 4. Single Leaf area of different okra cultivars as affected by humic acid levels. Each line represents the average leaf area of different okra cultivars in response to various levels of humic acid

\section{Number of leaves plant ${ }^{-1}$}

The findings of research study related with number of leaves of okra cultivars as affected by humic acid are shown in Figure 5. Data analysis showed significant influence on number of leaves plant $^{-1}$ of okra cultivars when humic acid was applied. Maximum (27.87) number of leaves plant $^{-1}$ were observed in cv. Pusa Sawani followed by Arka Anamika, while least (26.20) number of leaves plant $^{-1}$ were recorded in Green Star which was statistically at par with Sabz Pari. The difference in number of leaves might be correlated with the genotype of cultivars and climatic conditions of the research area. The suitable environmental conditions tends the plants more vigorous and produced maximum leaves. The results are supported by the findings of many researchers including; [18, 19] who found significant fluctuation in number of leaves of various okra cultivars. Application of humic acid @ $30 \mathrm{~kg}^{-1}$ respond well as compared to others and produced maximum (28.25) number of leaves plant $^{-1}$ which is statistically at par with $20 \mathrm{~kg}^{-1}$ while minimum (25.25) number of leaves plant $^{-1}$ were observed in control plots. The increase in number of leaves might be due to more uptakes of nutrient and suitable soil conditions due to the application of humic acid. The maximum availability and uptake of nutrients improved the plant growth and increase plant height which is the key factor for number of leaves. Similar study was also conducted by Brownell et al. [20] Yildirim [21] and Karakurt et al. [22] who stated that addition of humic acid increase the number of leaves of various species. 


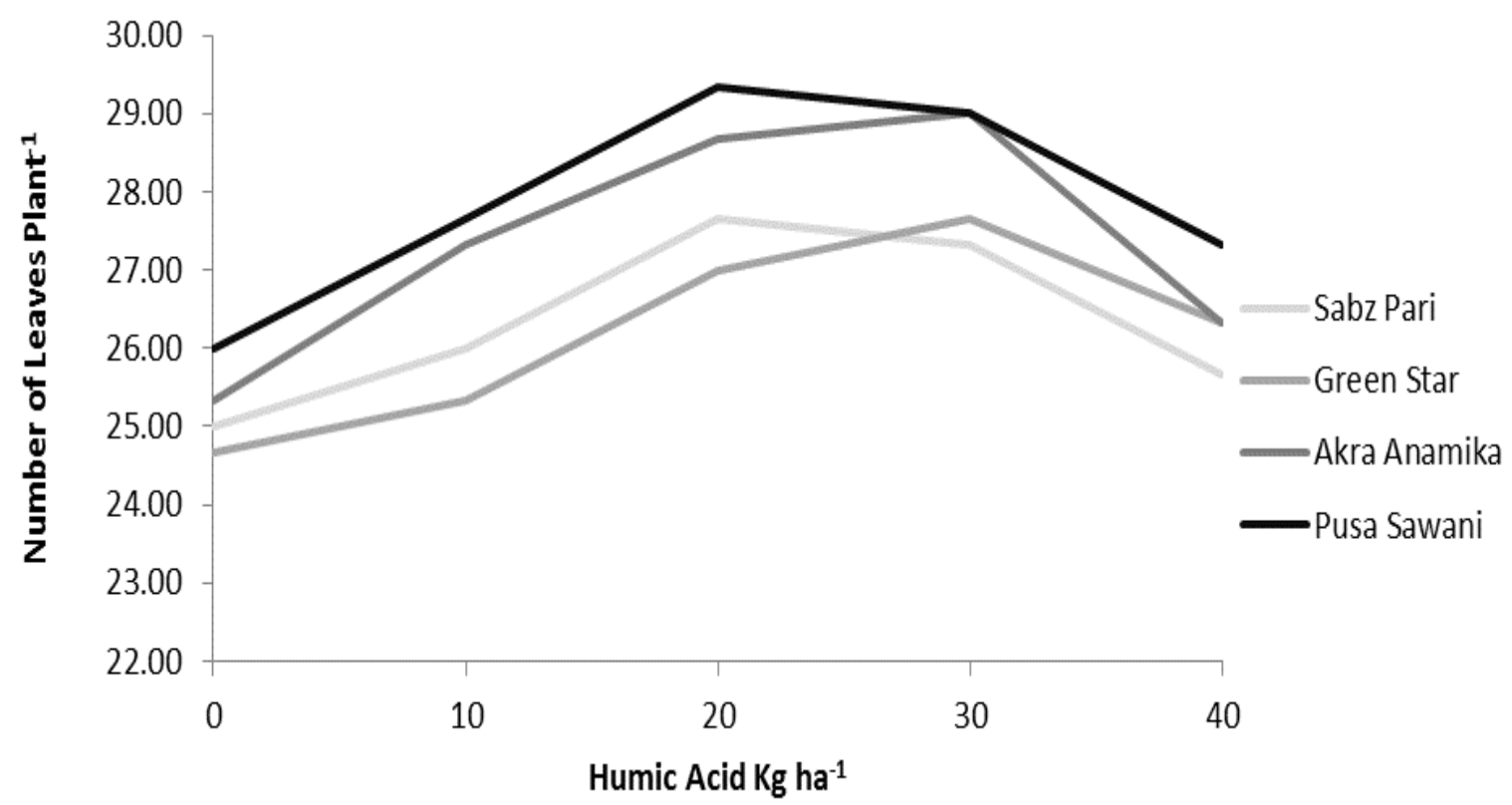

Figure 5. Number of leaves plant ${ }^{-1}$ of different okra cultivars as affected by humic acid levels. Each line represents the average number of leaves plant ${ }^{-1}$ of different okra cultivars in response to various humic acid levels

\section{Oven dried single leaf weight (g)}

Mean data about oven dried leaf weight are presented in Figure 6. Mean data showed significant effect of humic acid application on leaf weight of okra cultivars while the interaction was found non-significant. Maximum leaf dry weight (1.10 g) was recorded in cv. Sabz Pari followed by Arka Anamika while minimum (0.87 g) leaf dry weight was observed in Green Star. The variation in leaf dry weight might be due to the more competitive quality and suitability with environmental conditions of some cultivars than other. Maximum nutrient uptake such as Nitrogen and Phosphorous, and high photosynthetic efficiency result in maximum leaf dry weight. The results are correlated with the findings of [23] who reported significant variation in shoot fresh and dry weight of okra cultivars.

Maximum leaf dry weight (1.23 g) was recorded in the treatments where humic acid was applied @ $20 \mathrm{~kg} \mathrm{ha}^{-1}$ which was statistically at par with $30 \mathrm{~kg} \mathrm{ha}^{-1}$ whereas minim leaf dry weight $(0.75 \mathrm{~g})$ was noticed in control plots which was statistically at par with $40 \mathrm{~kg} \mathrm{ha}^{-1}$ humic acid. The increase in leaf dry weight might be due to the more availability and uptake of $\mathrm{N}$ and $\mathrm{P}$ with the application of humic acid because it plays a vital role in boosting the biochemical and biological processes, synthesis of chlorophyll and availability and uptake of nutrients [24]. The results are correlated with the findings of [14] who reported significant role of humic acid on leaf dry weight of okra. 


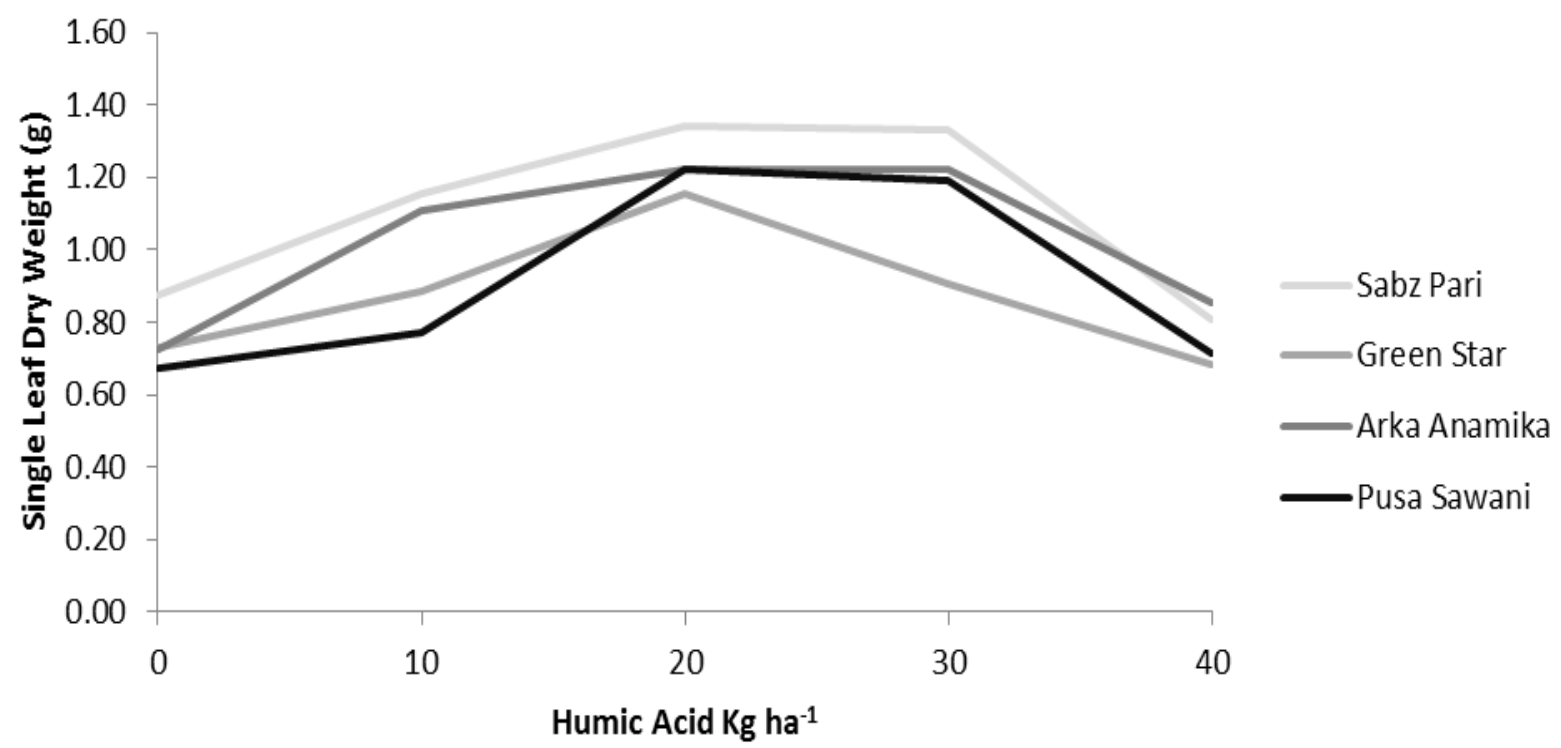

Figure 6. Single leaf dry weight of different okra cultivars as affected by humic acid levels. Each line represents the average single leaf dry weight of different okra cultivars in response to various levels of humic acid

\section{Production duration (days)}

Data regarding production duration of okra cultivars as affected by humic acid are shown in Figure 7. The findings of research showed significant role of humic acid application on the production duration of okra cultivars while the interactive affect was found non-significant. Long productive duration (74 days) was observed in cv. Arka Anamika followed by Sabz Pari while shortest (71.40 days) productive duration was noticed in cv. Green Star. The difference in production duration might be due to the combination of environmental conditions and genotype of cultivars. Some cultivars showed more suitability or adoptability to the environmental conditions of the area than others which result in long productive duration. The results are correlated with the findings of [25] who reported that environmental conditions of an area affected the developmental phases and whole life cycle of a plant.

Application of humic acid @ $20 \mathrm{~kg} \mathrm{ha}^{-1}$ significantly increased (74.50 days) the production duration of okra cultivars which is statistically at par with $30 \mathrm{~kg} \mathrm{ha}^{-1}$ while minimum (70.75 days) production duration was recorded where humic acid was applied @ $40 \mathrm{~kg} \mathrm{ha}^{-1}$. The variation in production duration might be due the early flowering because of humic acid application. Humic acid have the ability to improve soil fertility, nutrients availability, soil porosity and nutrients uptake of plant. Humic acid have the ability of anti-stress effect when plant with stands in unfavorable environmental conditions. A correlated study of [14] stated similar results who reported early picking in okra with the application of humic acid. Similarly [26] reported prolong blooming period in snapdragon when humic acid was applied. 


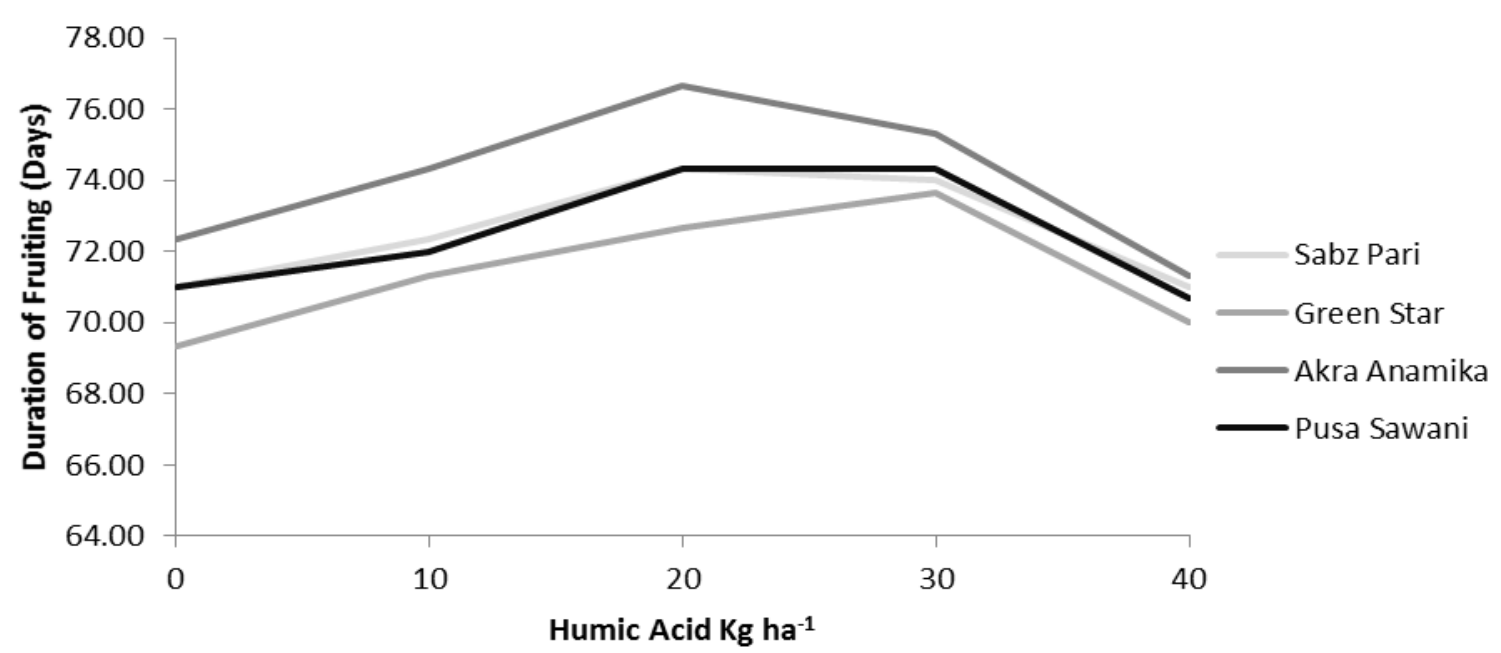

Figure 7. Influence of humic acid on fruiting duration of okra cultivars. Each line represents the average response of various okra cultivars to different levels of humic acid

\section{Conclusions}

From current study it was concluded that amendment of humic acid @ $20 \mathrm{~kg} \mathrm{ha}^{-1}$ have the potential to induce early fruiting and prolong production duration in okra plant. Similarly the application of humic acid improved the vegetative plant growth including leaf area as well. It was observed that cv. Arka Anamika responded well in almost all the studied characters which shows genetically superiority or more suitability of this cultivars with the climatic conditions of Dargai, district Malakand, Khyber Pakhtunkhwa, Pakistan and can be recommended for better growth and prolong production duration which will result in higher yield.

\section{Authors' contributions}

Conceived and designed the experiments: $\mathrm{N}$ Haider \& M Alam, Performed the Experiments: N Haider, M Alam, S Zeb \& W Haider, Analyzed the Data: N Haider, A Khan \& S Hussain, Contributed reagents/ materials/ analysis tools: $\mathrm{N}$ Haider, $\mathrm{S}$ Hussain, W Haider \& S Zeb, Wrote the paper: N Haider \& M Alam.

\section{References}

1. Naheed Z, Ayaz A, Rehman A, Khan NA, Ahmad SQ, Hamid FS, Waheed A, Asghar S \& Khan MS (2013). Agronomic traits of okra cultivars under agro-climatic conditions of Baffa (KPK) Pak J Mater Environ Sci 4(5): 655-662.

2. Amjad M, Sultan M, Anjum MA, Ayyub CM \& Mushtaq M (2001). Comparative study on the performance of some exotic okra cultivars. Int J Agric \& Bio 3(4): 423425.

3. Dash GB \& Misra PK (1995). Variation and character association of fruit yield and its component characters in okra. Current Agric Res 8: 123-127.

4. Calvo P, Nelson L \& Kloepper JW (2014). Agricultural uses of plant bio stimulants. Plant \& Soil 383(1): 3-41.

5. Pettit RE (2004). Organic matter, humus, humate, humic acid, fulvic acid and humin: Their importance in soil fertility and plant health. Available at http://fertiorganicos.com/english/images/lib /organic_matter_humus_humate_humic_aci d_fulvic_acid.pdf cti research. (Accessed 7 May 2015).

6. Brady NC \& Weil RR (2008). The nature and properties of soils. European $J$ Soil \& Bio 42(1): 65-69.

7. Petronio P, Vitorovic D \& Jablanovic M (1982). Investigation of biological effect of humic acid. Act Bio Med Exp 7:21-25.

8. Brannon CA \& Sommers LE (1985). Preparation and characterization of model 
humic polymers containing organic phosphorus. Soil Boi \& Bioche 17: 213219.

9. Kulikova NA, Stepanova EV \& Koroleva OV (2005). Use of humic substances to remediate polluted environments: from Theory to practice. springer Netherlands pp. 285-310.

10. Hussain S, Sajid M, Amin N, Alam S \& Iqbal Z (2006). Respons of okra (Abelmoschus esculentus) cultivars to different sowing times. J Agric \& Bio Sci 01(1): 55-59.

11. Sadiq WM, Amin N \& Zoor S (1988). Performance of okra cultivars under soil and climatic conditions of Peshawar. Sarhad J Agric 4(5): 633-637.

12. Bhardwaj KKR \& Gaur AC (1970). The effect of humic and fulvic acids on the growth and efficiency of nitrogen fixation of Azotobacter chroococcum. Folia Microbiologica 15(5): 364-367.

13. Haan DH (1974). Effect of fulvic acid fraction on the growth of a Pseudomonas from Tjeukemeer (Netherlands). Fres $W$ Bio 4: 30 1-310.

14. Kumar P, Rana DK, Singh V \& Shah KHN (2015). Effect of humic acid on growth, yield and quality of okra (Abelmoschus esculentus L.) cv. Arka Anamika under subtropical condition of Garhwal Himalaya. Int J I Res Sci Tech 9(8): 026-030.

15. Ade-Oluwa OO \& Kahinde BO (2011). Genetic variability studies in West African okra (Abelmoschus caillie). Agric \& Bio J North America 2(10): 1326-1335.

16. Akortkar PK, De DK \& Pal AK (2010). Genetic variability and diversity in okra (Abelmoschus esculentus L.) Moench Elec J Plant Breed 1(4): 393-398.

17. Haghighi S, Saki TN \& Lack SH (2011). Evaluation of changes the qualitation \& quantitative yield of horse been (Vicia fabal L.) plant in the levels of humic acid fertilizer. Life Sci J 8(4): 13-19.
18. Kumar S, Annapurna Y, Yadav C \& Singh R (2012). Genetic variability, heritability, genetic advance, correlation and path analysis in okra. Hort Flora Res Spec 1(2): 139-144.

19. Alam AK \& Hussain MM (2008). Variability of different growth contributing parameters of some okra (Abelmoschus esculentus L.) accessions and their interrelation effects on yield. $J$ Agric Rural Dev 6(2): 25-35.

20. Brownell JR, Nordstrom G, Marihart J \& Jorgensen G (1987). Crop responses from two new leonardite extracts. Sci Total Environ 62: 491-499.

21. Yildirim E (2007). Foliar and soil fertilization of humic acid affect productivity and quality of tomato. Acta Agri Scand Sec B -Soil \& Plant Sci 57(2): 182-186.

22. Karakurt Y, Unlu H \& Padem H (2009). The influence of foliar and soil fertilization of humic acid on yield and quality of pepper. Acta Agri Scandi Sec B Plant Soil Sci 59(3): 233-237.

23. Naz I, Khan H, Ali A, Ahmad M, Hussain A \& Tahir M (2009). Effect of various sowing dates and cultivars on the management of okra root rot under natural field conditions. S J A Vol. 25(2): 2009.

24. Javanmardim J \& Hasanshaian O (2014). Humic acid and manure tea affected reproductive stage and fruit quality factors of pepino in organic production system. 2: 23-30.

25. Cober ER \& Voldeng HD (2001). A new soybean maturity and photoperiod sensitiv e locus linked to E1 and T. Crop Sci 41: 698-701.

26. Memon SA \& Khetran K (2014). Effect of humic acid and calcium chloride on the growth and flower production of Snapdragon (Antirrhinum majus). J Agric 10(6): 1557-1569. 